\title{
A Scale Development for Teacher Competencies on Cooperative Learning Method
}

\author{
Ayfer Kocabas, Deniz Gokce Erbil" \\ Faculty of Education, Dokuz Eylul University, Turkey
}

Copyright $(\mathrm{C} 2017$ by authors, all rights reserved. Authors agree that this article remains permanently open access under the terms of the Creative Commons Attribution License 4.0 International License

\begin{abstract}
Cooperative learning method is a learning method studied both in Turkey and in the world for long years as an active learning method. Although cooperative learning method takes place in training programs, it cannot be implemented completely in the direction of its principles. The results of the researches point out that teachers have problems with the implementation of cooperative learning method, which is an active and democratic learning method. In spite of the fact that the reason of most of these problems is depended on the factors out of teachers, it is obvious that a scale is required in order to measure their competency levels in relative with the cooperative learning method, and to determine the qualification of the training they have obtained in university before serving, and to become a resource maybe for the in-service training studies in the future. In this research it is aimed to develop an assessment tool in order to measure the competency of teachers about the method by depending on the cognitive infrastructures, knowledge levels and implementation process of teachers, serving actively, for the cooperative learning method. Scale development studies were started on the theoretical basis of the cooperative learning method. The item preparation was carried out according to the significant features of the method such as positive interdependence, face-to-face interaction, individual accountability, interpersonal and small group skills, group processing and group award. The study group of the research consists of 236 teachers serving actively in 7 regions in Turkey. Data obtained from the scale was analyzed by using Cronbach's Alpha reliability co-efficient, item distinctiveness, item total point correlations and by determining $t$ test results performed between average points of each item of upper-lower $27 \%$ groups. In order to determine the structure validity of the scale, Exploratory Factor Analysis (EFA) and Confirmatory Factor Analysis (DFA) were constituted by making benefit of fit indexes. All the sub-sections of the scale indicate an acceptable reliability. Confirmatory Factor Analysis (CFA) performed to confirm this structure was made on the same data set of 236 conditions. The correlation between latent variable and observed variable as a result of CFA varies between .30 and .77. It has been found out that the structure of 21 items
\end{abstract}

and 3 factors have acceptable fit indexes $\left(\mathrm{x}^{2} / \mathrm{df}=2.40\right.$; RMSEA $=.08 ;$ SRMR $=.08 ;$ GFI $=.86 ;$ AGFI $=.82$; $\mathrm{CFI}=.91 ; \mathrm{NNFI}=.89$ ). Item analysis of the scale consists of 21 items after EFA and CFA, and the maximum point to be available is 105 and minimum point is 21 . Of 21,13 items are positive and 8 items are negative. The results of EFA and CFA points outs that the scale has three factor patterns named as "Preliminary and Planning", "Implementation Process" and "Evaluation". It can be expressed that the developed scale is the one presenting valid and reliable results, and that it can be utilized to determine the competency of teachers about cooperative learning method.

Keywords Cooperative Learning, Scale Development, Teacher Competencies

\section{Introduction}

All the teacher raising institutions were assigned to Council of Higher Education in the scope of Higher Education Law numbered 2547 introduced in Turkey in 1980, however it came into force. Therefore, all the teacher raising institutions were assembled under universities, and at least four-year-bachelor degree was stipulated for teachers in every level. (The duration of 2-year-Education Academies raising teachers was increased to 4 years beginning from the academic year 1992 - 1993). Re-configuration of education faculties was considered as obligatory according to a determination in the book published by Council of Higher Education in 1998 as "Education faculties face with various problems such as wrong configuration and deviating from its main purpose, and are inadequate both qualitatively and quantitatively to fulfil the requirement of the country for teacher. With the new configuration prepared in the academic year 1997-1998, and implemented in the academic year 1998-1999, the lessons of "Special Teaching Methods" were put forward. The teachers' competencies were determined as general and special competencies after applying the constructive 
teaching approach in "2006 Primary School Teaching Programs", and eight competency fields were constituted in the scope of "Special Field Competencies of Primary School Teaching" as "Learning and Teaching Environment and Development", "Follow-up and Evaluation", "Personal and Vocational Development - Relations with Society", "Art and Esthetics", "Development of Linguistic Skills", "Scientific and Technological Improvement", "Personal Responsibilities and Socializing" and "Physical Education and Safety" (MEB, 2008). The competencies of each field were determined and the performance indicators were mentioned in three stages as A1, A2 and A3. Of these field competencies, "Learning and Teaching Environment and Development" and "Personal Responsibilities and Socializing" include learning and teaching methods, knowledge and skills. In general, cooperative learning method took place in 2006 Primary School Teaching Programs as an active learning method to implement in all lessons (MEB, 2006).

Cooperative learning is defined as using small groups for educational purposes (Johnson, Johnson ve Holubec, 1994). Kagan (1994) defines cooperative learning method as a learning method to enable students to work in small and heterogeneous groups and present a product and share this product with all the class. Sharan, Sharan and Gentile define cooperative learning as an internal relationship type among the students while trying to achieve a target. (as cited in Panitz, 1999). In order to obtain a real cooperation and product by means of cooperative learning method, the principles or conditions of cooperation should be fulfilled. These conditions are determined as

- Positive interdependence,

- Individual accountability

- Face-to-face promotive interaction

- Interpersonal and small group skills

- $\quad$ Group processing

- Preparing a group award (Johnson, Johnson and Holubec, 1994).

In the meta-analysis studies carried out by Johnson, Johnson and Stanne (2000) internationally, it was found out that many benefits could be made for cognitive and social gaining with the correct implementation of cooperative learning method, and according to the study of that Kocabas et al. (2015) in Turkey, it was determined that cooperative learning affected different variables positively in $80 \%$ of 70 postgraduate thesis in Turkey, and in $16 \%$ partially positively, and in $4 \%$ with the similar effects with the other methods.

In spite of the researches indicating the efficiency of cooperative learning and of implementation of the method in training programs, there are research results indicating that the conditions of the cooperative learning are not fulfilled and accordingly it is not implemented efficiently.

The roles of teacher are so important in the implementation of cooperative learning. According to this aspect, the main problem related to the implementation is that teachers define and consider the implementation process of the method as "hard" (Cohen, 1994). These hardness points are that teachers do not know how to set the cooperative learning group efficiently and they cannot reflect the researches related to theory and practice of the method to the class environment (Gillies, Ashman \& Terwel, 2008). According to Gillies (et al. 2008), if the teacher does not competent for cooperative learning, it is obvious that he/she will face with various problems in the process of implementation, of course. It has been emphasized in the literature that the knowledge of teachers how to adopt cooperative learning to class environment and training program is quite important in order to develop the communication and dependence of teacher-student, and to support the cooperative research and ability to solve problems, and to enable the students to feel in safe in the class environment (Johnson \& Johnson, 2003; Roseth, Johnson, \& Johnson, 2008). Blatchford et al. (2003) has emphasized that both teachers and students should be trained before the implementation in order to apply in the best and correct way. This training includes preparing the program during the cooperative learning process, providing the students with interpersonal and small group skills and informing teachers how to carry out training together with groups. Gillies and Boyle (2010) has obtained the result that teachers fell themselves as inadequate in the implementation process of cooperative learning method. In this research, teachers expressed positive opinions in the aspects of lesson management and students' studies in small group about the implementation of cooperative learning basically. The main hard points which teachers face with are socializing problems within the groups, time management and organization and planning required for the implementation of cooperative learning. Heterogeneity of group members and the subject types required for the motivation of each student take place in the hard points which teachers face with. In addition, teachers have mentioned that students need a preliminary preparation in the subjects such as small group skills and ability to solve conflicts.

According to Akay and Kocabaş (2013), teachers have stated that they could not implement the active learning methods and the implementation was hard although they had knowledge about the active learning methods. The research results have indicated that the frequency of teachers to use different methods and technics was very low, and that they thought that the problems related with the implementation of active learning methods were caused generally by curriculum, school management, parents and students. In the research made by Gökçe (2004), the result has been obtained that active learning process could not be implemented adequately in primary school, and that students could not participate in the planning process of training principles although teachers expressed that active learning presented benefits to the students. In the study of Bulut (2005), the active learning was affected negatively due to the problems such as physical conditions of school, 
inadequate equipment-device, and not evaluating teachers in the system of inspection and supervisory according to active learning, inadequacy of teachers in active learning, implementation inefficacy and the tendency of teachers to traditional training perception.

When examining the results of researches in Turkey and the world, a main difference attract the attention. The international researches points out that the reason of the problems in the implementation process of the method is knowledge inadequacy of the teachers in theoretical field. Teachers do not know the cooperative learning method completely, and even if they know, they cannot reflect the knowledge to the implementation process. The reason of the most problems in our country is based on the factors out of teachers generally. There is a condition contradicting each other.

The teachers in Turkey consider that they know the method well, but the problems in the implementation are caused by the reasons out of themselves. In this regard, there is a necessity to measure their competency levels in relative with the cooperative learning method, and to determine the qualification of the education they have obtained in university before serving, and to become a resource maybe for the in-service training studies in the future. This developed scale can evaluate the difference variants related to learning processes, student and teacher qualifications, training environment and methods and can direct the researches by presenting valid and reliable measurement results to determine the conditions in relative with the implementation level of cooperative learning method. In this research, by taking action to fulfil the requirement in this field, it is aimed to develop a measurement tool of their competencies related to the method by depending on the cognitive infrastructure of teachers about cooperative learning method, knowledge levels and implementation process. However, modern training required a student-centered training and training methods in all levels. Cooperative learning leads student-centered, active and democratic learning method (Johnson, Johnson and Holubec, 2005:1-4). Measuring the implementation efficiency of cooperative learning method, a valid and reliable measurement tool seems significant from the point of implementing and evaluating this method, and making benefit of positive outcomes more tangibly, and feeding back the teachers. Moreover, this scale will be basis for internal validity of descriptive and experimental researches in order to obtain valid and reliable measurement results as a valid and reliable tool.

\subsection{Research Question}

For this purpose, the problem sentence of the research was determined as "How should a valid and reliable measurement tool be for the competencies of teachers in relative with cooperative learning method?

\section{Method}

\subsection{Research Design}

In this research, an explorative/explorer pattern is used. In this pattern, first the qualitative data is collected and later these data are used in order to guide the collection of quantitative data (Büyüköztürk et al, 2012:247).

\subsection{Studies to Improve the Scale}

Scale improvement studies started on the theoretical basis of the collaborative learning method. The important features of the method is ,positive dependency, one-to-one supportive interaction, individual evaluability, interpersonal and small group abilities, evaluation of the group process and group prizes are taken as basis when writing the items. At this stage, 48 items were examined by 3 experts. The experts chose not to drop any items but made only some wording changes.

\subsection{Working Group}

The working group consists of 236 teachers that work actively in 7 regions of Turkey that were chosen without prescreening.

\subsection{Data Collection Tool}

A 48 item trial form was turned into a 5 level liker type scale and progressed into reliability studies. The answers "Definitely Agree", "Agree", "Undecided", "Disagree", "Definitely Disagree" are labelled respectively from 5 to 1 . On the trial form, 16 items were considered negative items and their points were codified backwards. The highest point possible on the trial form was 240 and the lowest was 48 . A higher point means that the teacher has a higher competency in cooperative learning.

\subsection{Data Collection Process}

To reach a broader working group within the scope of the research, the scale was uploaded to a questionnaire website and the related internet address was sent to the teachers through e-mail or social network sites. 150 of the teachers filled the scale through the internet and the remaining 76 in a physical environment. The implementation lasted on the internet approximately 15 minutes and in the physical environment, 20.

\subsection{Analyzing the Data}

In the analysis of the data, Cronbach's Alpha reliability coefficient, item distinctiveness are evaluated by determining the total item point correlations. In order to determine the structural validity of the scale, Exploratory Factor Analysis (EFA) and Confirmatory Factor Analysis (CFA) are made with the help of conformity indexes. 


\section{Results}

\subsection{Item Analysis}

Table 1. Item Analysis Results

\begin{tabular}{|c|c|c|c|}
\hline Item & $\begin{array}{c}\text { Adjusted Item } \\
\text { Total } \\
\text { Correlation } \\
\end{array}$ & $\begin{array}{l}\text { Cronbach's } \\
\text { Alpha if the item } \\
\text { is dropped }\end{array}$ & $\begin{array}{c}\mathrm{t} \\
\text { upper \%27 } \\
\text { lower \%27 }\end{array}$ \\
\hline 1 & 0,24 & 0,89 & $4,093^{*}$ \\
\hline 2 & 0,35 & 0,89 & $5,132 *$ \\
\hline 3 & 0,29 & 0,89 & $4,76^{*}$ \\
\hline 4 & 0,26 & 0,89 & $4,181 *$ \\
\hline 5 & 0,20 & 0,89 & $3,069^{*}$ \\
\hline 6 & 0,25 & 0,89 & $4,673 *$ \\
\hline 7 & 0,40 & 0,89 & $6,74 *$ \\
\hline 8 & 0,41 & 0,89 & $4,98^{*}$ \\
\hline 9 & 0,40 & 0,89 & $4,83^{*}$ \\
\hline 10 & 0,32 & 0,89 & $5,181^{*}$ \\
\hline 11 & 0,31 & 0,89 & $4,969^{*}$ \\
\hline 12 & 0,44 & 0,89 & $5,944 *$ \\
\hline 13 & 0,33 & 0,89 & $6,033^{*}$ \\
\hline 14 & 0,40 & 0,89 & $4,138^{*}$ \\
\hline 15 & 0,32 & 0,89 & $3,93 *$ \\
\hline 16 & 0,32 & 0,89 & $3,902 *$ \\
\hline 17 & 0,33 & 0,89 & $4,529 *$ \\
\hline 18 & 0,45 & 0,89 & $6,463 *$ \\
\hline 19 & 0,48 & 0,88 & $8,78^{*}$ \\
\hline 20 & 0,57 & 0,88 & $7,364 *$ \\
\hline 21 & 0,10 & 0,89 & 0,988 \\
\hline 22 & 0,45 & 0,89 & $6,178^{*}$ \\
\hline 23 & 0,38 & 0,89 & $4,58^{*}$ \\
\hline 24 & 0,40 & 0,89 & $5,03 *$ \\
\hline 25 & 0,42 & 0,89 & $6,148^{*}$ \\
\hline 26 & 0,40 & 0,89 & $4,94^{*}$ \\
\hline 27 & 0,51 & 0,88 & $6,862^{*}$ \\
\hline 28 & 0,49 & 0,88 & $7,058^{*}$ \\
\hline 29 & 0,26 & 0,89 & $4,212^{*}$ \\
\hline 30 & 0,30 & 0,89 & $3,357^{*}$ \\
\hline 31 & 0,39 & 0,89 & $4,866^{*}$ \\
\hline 32 & 0,50 & 0,88 & $7,118^{*}$ \\
\hline 33 & 0,45 & 0,89 & $5,882^{*}$ \\
\hline 34 & 0,46 & 0,89 & $5,417^{*}$ \\
\hline 35 & 0,55 & 0,89 & $6,639^{*}$ \\
\hline 36 & 0,52 & 0,89 & $6,114^{*}$ \\
\hline 37 & 0,28 & 0,89 & $3,746^{*}$ \\
\hline 38 & 0,40 & 0,89 & $7,439 *$ \\
\hline 39 & 0,37 & 0,89 & $7,018^{*}$ \\
\hline 40 & 0,36 & 0,89 & $7,512^{*}$ \\
\hline 41 & 0,20 & 0,89 & $3,242 *$ \\
\hline 42 & 0,31 & 0,89 & $5,361^{*}$ \\
\hline 43 & 0,50 & 0,88 & $6,968^{*}$ \\
\hline 44 & 0,44 & 0,89 & $6,77^{*}$ \\
\hline 45 & 0,28 & 0,89 & $3,819^{*}$ \\
\hline 46 & 0,39 & 0,89 & $8,307^{*}$ \\
\hline 47 & 0,34 & 0,89 & $4,477^{*}$ \\
\hline 48 & 0,41 & 0,89 & $4,958^{*}$ \\
\hline
\end{tabular}

*significant at 0,05

Before EFA, to understand how much the variance of each item contributes to the total variance of the item, an item analysis was conducted. Therefore, adjusted total correlation of an item, Cronbach's Alpha reliability value if the item is deleted and average points of each item in groups of upper and lower $\% 27$ were used in a t test (Figure 1). When the total correlations of the items are analyzed, it is seen that they are between .10 and .57. A higher total point correlation of items shows that the participants gave more similar answers to the items (Can, 2013:344). According to Büyüköztürk (2013), an adjusted total item point correlation bigger than 0.30 shows that the items are good and if they are between 0.20 and 0.30 , they can be included in the scale if necessary. So, the 21th item was excluded since both its adjusted item total correlation value was low and sit did not yield a significant $t$ value and therefore was lowering the inner reliability of the scale.

\subsection{Exploratory Factor Analysis}

Principal component analysis, one of EFA methods was used in order to find the factor structure of the scale. In order to determine if the scale is suitable for factor analysis, Kaiser Meyer Olkin and Barlett tests were used. In Figure 1, $\mathrm{KMO}$ and Barlett test results can be seen regarding the pre-implementation of the test.

Table 2. KMO and Barlett Test Results

\begin{tabular}{ccc}
\hline \multicolumn{2}{c}{ Kaiser Mayer Olkin } &, 814 \\
(KMO) Value & Chi-square & 4522,230 \\
Barlett Test & df & 1081 \\
& Sig. &, 000 \\
\hline
\end{tabular}

The KMO value being close to 1 shows that the sample size is suitable for the chosen analysis; and the Barlett Test result being significant $(\chi 2=4522,230 ; p<.000)$ shows that the data come from a normal distribution (Büyüköztürk, 2013).

As a result of EFA, considering the lateral buildup graphs and real values, it is determined that their contribution to the total variance can be expressed in three factors. Eigenvalue factor graphics of the scale is given in Figure 1.

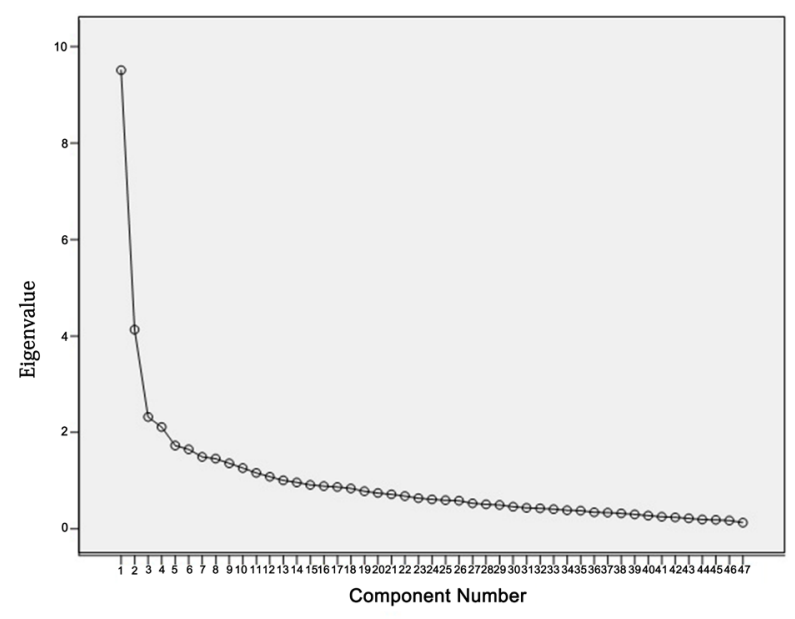

Figure 1. Eigenvalue Factor graph of the Scale 
Table 3. Item factor loads and Joint factor loads after Varimax

\begin{tabular}{|c|c|c|c|c|}
\hline \multirow[t]{2}{*}{ Item \# } & \multicolumn{3}{|c|}{ Factor } & \multirow{2}{*}{$\begin{array}{c}\text { Common } \\
\text { Factor } \\
\text { Loads }\end{array}$} \\
\hline & $\begin{array}{c}\text { Preparation } \\
\text { and } \\
\text { Planning }\end{array}$ & $\begin{array}{c}\text { Implementation } \\
\text { Process }\end{array}$ & Evaluation & \\
\hline 13 & 0,69 & $-0,02$ & 0,07 & 0,48 \\
\hline $4 *$ & 0,68 & 0,07 & $-0,04$ & 0,48 \\
\hline $5 *$ & 0,62 & 0,10 & $-0,13$ & 0,41 \\
\hline $10^{*}$ & 0,58 & $-0,07$ & 0,29 & 0,42 \\
\hline $1 *$ & 0,52 & $-0,05$ & 0,16 & 0,30 \\
\hline $11^{*}$ & 0,44 & 0,17 & 0,06 & 0,23 \\
\hline 36 & $-0,04$ & 0,80 & 0,00 & 0,64 \\
\hline 35 & 0,02 & 0,78 & 0,13 & 0,62 \\
\hline 27 & 0,06 & 0,72 & 0,09 & 0,54 \\
\hline 33 & $-0,05$ & 0,69 & 0,12 & 0,49 \\
\hline 31 & $-0,12$ & 0,67 & 0,18 & 0,50 \\
\hline $34 *$ & 0,21 & 0,61 & $-0,08$ & 0,42 \\
\hline 26 & $-0,04$ & 0,60 & 0,05 & 0,36 \\
\hline 28 & 0,01 & 0,60 & 0,27 & 0,43 \\
\hline 23 & 0,11 & 0,55 & $-0,17$ & 0,34 \\
\hline 32 & 0,07 & 0,54 & 0,39 & 0,45 \\
\hline 22 & 0,25 & 0,53 & $-0,10$ & 0,35 \\
\hline $40 *$ & $-0,06$ & 0,31 & 0,71 & 0,61 \\
\hline 41 & 0,12 & $-0,18$ & 0,69 & 0,53 \\
\hline 42 & 0,17 & 0,06 & 0,55 & 0,33 \\
\hline $39 *$ & 0,02 & 0,36 & 0,50 & 0,38 \\
\hline
\end{tabular}

*Negative items are reversed

As a result of the Varimax vertical axis turn, 26 items that score lower than 0.45 in item load value are dropped by examining them one by one. Büyüköztürk (2013) states that a factor load value bigger than 0.45 is a good measure for the selection but suggests that for a few items, this rule can be 0.30 . The analysis is repeated for 3 items and it is seen that their total contribution to variance is $44.29 \%$. Each factor respectively contributes $23.77 \%, 12.57 \%$ and $7.95 \%$. For social sciences, the variance values between $40 \%$ and $60 \%$ are accepted and for a factor to be significant, at least 5\% of the declared variance should belong to that factor (Çokluk et al., 2010; Tavşancıl, 2010). Therefore, the value of $44.29 \%$ of the total declared variance is between the limit values.

3 factors and 21 items, resulting from the Varimax vertical axis turning, are named "Preparation and Planning", "Implementation Process" and "Evaluation", considering the theoretical basis of Cooperative Learning Method. "Preparation and Planning" consists of 6 items and the load values of these items vary between .69 and .44 . Those of "Implementation Process" vary between .71 and .50. Büyüköztürk (2013) states that a factor load value bigger than 0.45 is a good measure for the selection but suggests that for a few items, this rule can be 0.30 . Therefore, factor load values can be considered good (Field, 2009).

The post EFA state of the scale consists of 21 items and the maximum points to be taken is 105 , the minimum 21 . Of these 21 items, 13 are positive and 8 are negative. EFA results show that the scale has three factor patterns that can be called "Preparation and Planning", "Implementation Process" and "Evaluation".

In order to demonstrate the inner consistency of the points taken from the scale, Cronbach's Alpha Coefficient and the correlations between factors are analyzed for each factor. The reliability coefficients in "Preparation and Planning", "Implementation Process" and "Evaluation" sub-sections are respectively .66, .86 and .60. The correlations of these sub-sections are likewise respectively $(\mathrm{r}=.13, \mathrm{p}<.05$, $\mathrm{N}=236),(\mathrm{r}=.28, \mathrm{p}<.01, \mathrm{~N}=236)$ and $(\mathrm{r}=.20, \mathrm{p}<.01$, $\mathrm{N}=236$ ) and are statistically significant. All the sub-sections of the scale are reliable in an acceptable framework.

\subsection{Confirmatory Factor Analysis (CFA) Results}

A CFA is performed in order to determine the verification of the three sub-section model obtained after the EFA analysis. CFA is realized on the 236 condition dataset for three factors on the LISREL software and a covariance matrix is built. 


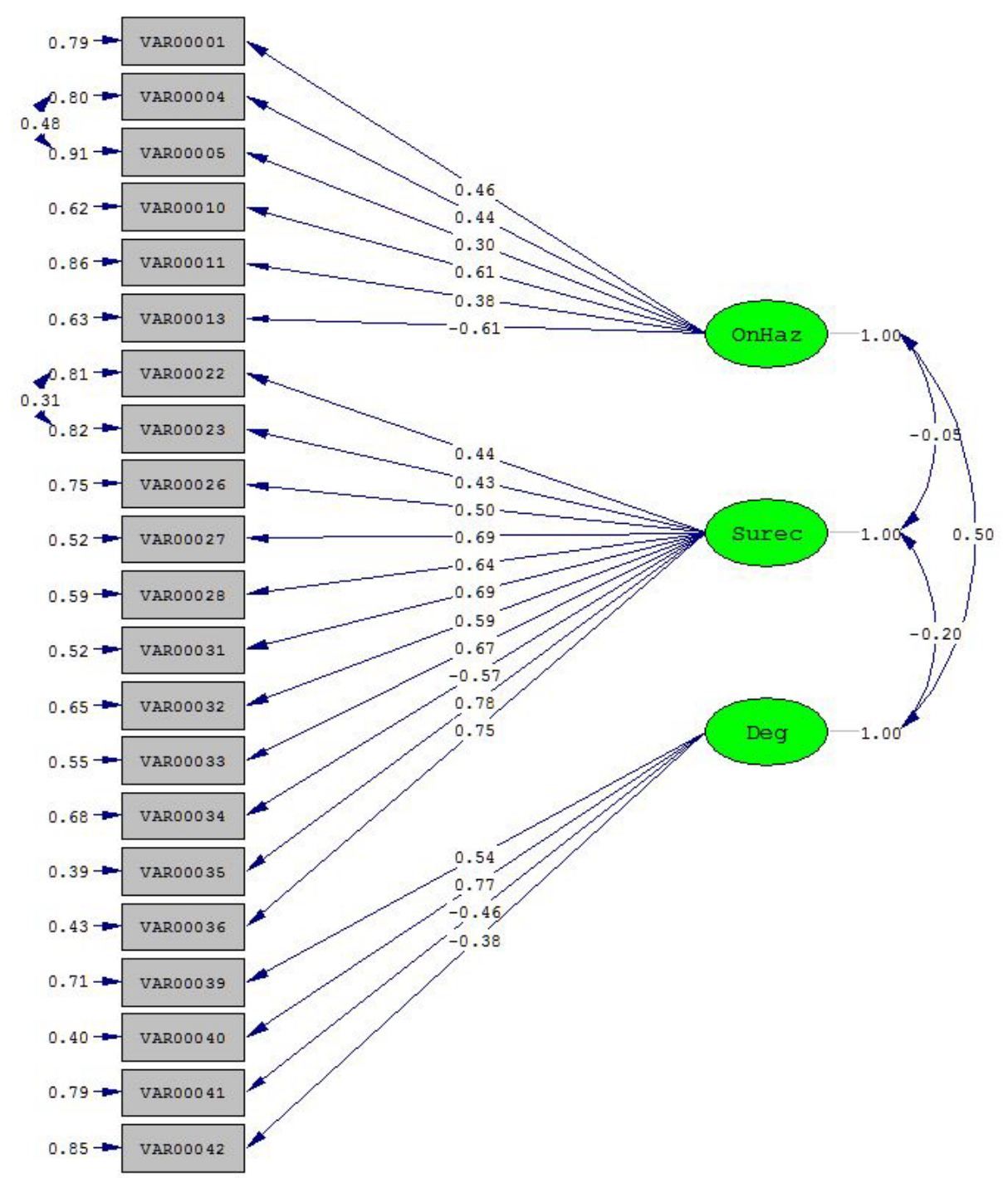

Chi-Square $=441.50, \mathrm{df}=184, \mathrm{P}-\mathrm{value}=0.00000, \mathrm{RMSEA}=0.077$

Figure 2. CFA Results of the scale and Error Variances

In the model, "Preparation and Planning", "Implementation Process" and "Evaluation" are represented respectively with 6,11 and 4 items. The relation between potential variables and observable variables vary between .30 and .77 . All the observable variables yield a significant $t$ value of .05 . Three factors verify each other and this can be interpreted as the factor load values of the scale are acceptable.

As a result of the CFA analysis, considering the modification recommendations, a modification is agreed upon thinking that is will significantly contribute $\mathrm{x}^{2}$ among the 4th, 5th, 22nd and 23rd items. 4th and 5th items contain the negative aspects of the method regarding time and 22nd and $23 \mathrm{rd}$ items contain the evaluation of the self-regulating competencies about the works of the group members and this is thought to be the reason of the modification recommendation.

Looking at the CFA results, $\mathrm{x}^{2} / \mathrm{sd}$ ratio is seen to be 2.399 . A ratio below 3 is defined as the perfect ratio. RMSEA value is acceptable and is 0.08. Likewise, GFI and AGFI values are .86 and .82 which is acceptable. With a CFI value of .91 and NNFI value of .89 mean that the hypothesized model is verified considering the acceptable conformity value is 0.90 . The fact that some conformity values are perfect and some are acceptable or very close to acceptable, shows that the hypothesized model can be verified with data (Jöreskog and Sörböm, 1993; Sümer, 2000; Çokluk, Şekercioğlu and Büyüköztürk, 2012).

Table 4. Conformity Indices After CFA

\begin{tabular}{cc}
\hline Conformity Indices & Conformity \\
\hline $\mathrm{x}^{2} / \mathrm{df}$ & 2.40 \\
RMSEA & .08 \\
Standardized RMR & .08 \\
$\mathrm{GFI}$ & .86 \\
$\mathrm{AGFI}$ & .82 \\
$\mathrm{CFI}$ & .91 \\
$\mathrm{NNFI}$ & .89 \\
\hline
\end{tabular}




\section{Results and Discussion}

The purpose of this research was to develop a scaling tool in order to measure the competencies of actively employed teachers about the cooperative learning method considering their cognitive foundations, levels of information and implementation processes. The research of developing a scale started on the theoretical basis of the cooperative learning method. 48 items are written considering the important features of the method such as positive interdependence, face to face interaction, individual accountability, interpersonal and small group skills, group processing and group award. The working group of the research consists of 236 teachers actively employed in all 7 regions of Turkey. In the analysis of the data collected from the scale, Cronbach's Alpha reliability coefficient, item distinctiveness, item total point correlations, $t$ test results of average points of upper and lower $27 \%$ groups' are used. As a result of the item analysis, an item was dropped due to a low adjusted item total correlation value and due to not giving an insignificant $t$ value and therefore lowering the inner reliability of the scale. An Exploratory Factor Analysis (EFA) is conducted in order to determine the structural validity of the scale and a Confirmatory Factor Analysis (CFA) using the conformity indices. As a result of the exploratory factor analysis, conducted with 47 items, the scale is found to have $3 \mathrm{sub}$ structures and a pattern on 21 items explaining $44.28 \%$ of the total variance. Each factor contributes to the common variance respectively with $23.27 \%, 12.57 \%$ and $7.95 \% .3$ factors and 21 items, obtained from the Varimax vertical axis turning, are named "Preparation and Planning", "Implementation Process" and "Evaluation". "Preparation and Planning" consists of 6 items and load values of this factor vary between .69 and .44. "Implementation Process" consists of 11 items and factor load values of the lower section vary between .80 and .53. "Evaluation" factor consists of 4 items and their load values vary between .71 and .50. Cronbach's Alpha coefficient of each factor and the correlations of factors are analyzed in order to find the inner consistency of the obtained points from the scale. Reliability coefficients of the Preparation and Planning, Implementation Process and Evaluation sub-sections are respectively .66, .86 and .60. The correlation between "Preparation and Planning" and "Implementation Process" is $(\mathrm{r}=.13, \mathrm{p}<.05, \mathrm{~N}=236)$, between "Preparation and Planning" and "Evaluation" is $(\mathrm{r}=.28, \mathrm{p}<.01, \mathrm{~N}=236)$ and between "Implementation Process" and "Evaluation" is $(\mathrm{r}=.20, \mathrm{p}<.01, \mathrm{~N}=236)$ and all are statistically significant.

All the sub-sections of the scale present acceptable reliability. Confirmatory Factor Analysis, carried out to correct this structure, was performed on the same data set of 236 conditions. As a result of CFA, the correlation between latent variable and observed variable vary between .30 and .77. It has been determined that all the observed variables indicate meaningful $t$ value in the level of .05 . It has been found out that the structure of 21 items and 3 factors have acceptable fit indexes $\left(\mathrm{x}^{2} / \mathrm{df}=2.40 ; \mathrm{RMSEA}=.08\right.$; $\mathrm{SRMR}=.08 ; \mathrm{GFI}=.86 ; \mathrm{AGFI}=.82 ; \mathrm{CFI}=.91 ; \mathrm{NNFI}=.89$ ). Item analysis of the scale consists of 21 items after AFA and DFA, and the maximum point to be available is 105 and minimum point is 21 . Of 21,13 items are positive and 8 items are negative. The results of EFA and CFA points outs that the scale has three factor patterns named as "Preliminary and Planning", "Implementation Process" and "Evaluation". It can be expressed that the developed scale is the one presenting valid and reliable results, and that it can be utilized to determine the competency of teachers about cooperative learning method.

When examining the results of researches in Turkey and the world, a main difference attract the attention. The international researches points out that the reason of the problems in the implementation process of the method is knowledge inadequacy of the teachers in theoretical field. Teachers do not know the cooperative learning method completely, and even if they know, they cannot reflect the knowledge to the implementation process. Teachers have inadequate knowledge related to theoretical background of cooperative learning, and do not know the group and peer working dynamics or how to realize training in small groups and peer relations (Cohen, 1994; Gillies et al., 2008; Gillies, 2008; Johnson \& Johnson, 2003; Roseth, Johnson, \& Johnson, 2008; Blatchford, Kutnick, Baines, and Galton, 2003; Gillies and Boyle, 2010). The reason of the most problems in our country is based on the factors out of teachers generally. Teachers suppose that they have knowledge about cooperative learning method, and consider that problems in implementation process of the method are caused by reasons out of themselves (Bulut, 2005; Gökçe, 2004; Akay and Kocabaş, 2013). There is a condition conflicting each other. By contract with the other colleges in the world, the teachers in our country think that they know the method well, but the problems in the implementation are caused by reasons out of themselves. In this regard, there is a necessity to measure their competency levels in relative with the cooperative learning method, and to determine the qualification of the education they have obtained in university before serving, and to become a resource maybe for the in-service training studies in the future. First of all, it is required to determine the competencies of teachers about the method, and to clarify this conflicting condition in the research. Thus, the aspects will be clarified such as the reasons for inability to implement the method in our country, and whether the problem is caused by reasons out of teachers or not, and whether there is a cognitive inadequacy of teachers about the method. These results will constitute a basis for principals and authorized persons of ministry to make decisions more correctly and to create a policy from the point of usage of cooperative learning method more efficiently and correctly.

It can be said that the developed measurement tool is a tool presenting valid and reliable results, and that it can be utilized in pre/post service and self-evaluation in order to 
determine the competencies of teachers about the cooperative learning method.

\section{Suggestions}

- It can be used both in teacher formation programs and in in-training programs.

- It can be used in local and international groups of different socio-cultural and economical levels by increasing the sample, and working on the validity and reliability. The collaborative teaching competencies of teachers of different countries can be compared.

- It contributes to the variety of the measuring tools since researches executed with valid and reliable measuring tools are the prerequisite of reliable research results.

\section{REFERENCES}

[1] Akay, Y., Kocabaş, A. (2013). Sınıf Öğretmenlerinin Aktif Öğrenmeyi Nasıl Algıladıklarına İlişkin Görüşleri. Ankara University Journal of Faculty of Educational Sciences, 46 (2), 91-110.

[2] Blatchford, P., Kutnick, P., Baines, E., \& Galton, M. (2003). Toward a social pedagogy of classroom group work. International Journal of Educational Research, 39(1), 153-172.

[3] Bulut, P. (2005). Okul Öncesi Aktif Öğrenme Modelinin Uygulanabilirliği. Yayınlanmış Yüksek Lisans Tezi. Fırat Üniversitesi Sosyal Bilimler Enstitüsü, Elazığ.

[4] Büyüköztürk, Ş. (2013). Sosyal bilimler için veri analizi el kitabı. Ankara: PegemA Yayıncılık.

[5] Büyüköztürk, Ş. vd.(2012). Bilimsel araştırma yöntemleri. Ankara, PegemA Yayıncılik.

[6] Can, A. (2013). SPSS ile bilimsel araştırma sürecinde nicel veri analizi. Ankara, PegemA Yayıncılık.

[7] Cohen, E. (1994). Restructuring the classroom: Conditions for productive small groups. Review of Educational Research, 64, $1-35$.

[8] Çokluk, Ö., Şekercioğlu, G. ve Büyüköztürk, Ş. (2012). Sosyal Bilimler İçin Çok Değişkenli İstatistik SPSS ve Lisrel Uygulamaları. Ankara: Pegem Akademi.

[9] Erbil, D. G., Kocabaş, A. (2015). İşbirlikli Öğrenme Yoluyla İlkokul Üçüncü Sınıf Öğrencilerinin Yansitıcı Düşünme Becerilerinin Geliştirilmesi. International Journal of Curriculum and Instructional Studies, 5(9).

[10] Gillies, R. M., \& Boyle, M. (2010). Teachers' reflections on cooperative learning: Issues of implementation. Teaching and teacher Education, 26(4), 933-940.

[11] Gillies, R. M., Ashman, A., \& Terwel, J. (Eds.). (2008). The teacher's role in implementing cooperative learning in the classroom. New York: Springer.

[12] Gökçe, E. (2004). İlköğretimde Aktif Öğrenmenin Öğrenciler
Üzerindeki Etkisi. XII. Eğitim Bilimleri Kongresi Bildirileri Ankara: Gazi Üniversitesi Eğitim Bilimleri Enstitüsü, I: 213-232.

[13] Jacobs, G. M., Lee, C, \& Ng, M. (1997). Co-Operative Learning In The Thinking Classroom. Paper presented at the International Conference on Thinking, Singapore.

[14] Johnson D. W., Johnson, R. T. ve Holubec, J. E. (1994). Nuts $\&$ bolts of cooperative learning. Minnesota: Interaction.

[15] Johnson D. W., Johnson, R. T. ve Holubec, J. E. (2005). Cooperative Learning, The Cooperative Link. The Newsletter of the Cooperative Learning Institute, Volume.20, Issue 1 March,

[16] Johnson D. W., Johnson, R. T.(1999). Learning Together and Alone, Cooperative Competetive and Individualistic Learning, Fifth Edition, Massachusetts, Allyn and Bacon A Viacom Company.

[17] Johnson D. W., Johnson, R. T., Smith, K.(1991). Active Learning: Cooperation in the College Classroom, Interection Book Company, Edina, MN.

[18] Johnson, D. W., Johnson, R. T. ve Stanne, M. B. (2000). Cooperative Learning Methods: A Meta-Analysis. Minnesota: University of Minnesota.

[19] Johnson, D., \& Johnson, R. (2003). Student motivation in cooperative groups: Social interdependence theory. In R. Gillies \& A. Ashman (Eds.), Cooperative learning: The social and intellectual outcomes of learning in groups (pp. 136-176). London: RoutledgeFalmer.

[20] Jöroskog, K. G. ve Sörböm, D. (1993). Lisrel 8: Structural Equation Modeling with the Simplis Command Language. Lincolnwood: Scientific Software International Inc.

[21] Kagan, S. (1994). Cooperative learning (Vol. 2). San Juan Capistrano, CA: Kagan Cooperative Learning.

[22] Kocabaş, A. (1998). İşbirlikli ve Geleneksel Öğrenme Yöntemlerinin Müziğe İlișkin Tutumlar Üzerindeki Etkisi. TED Eğitim ve Bilim Dergisi, 22, 36-40.

[23] Kocabaş, A., Aş1k, A., Karaşahin, İ., Erbil, D. G., Erdoğan, F. (2015). Türkiye'de İşbirlikli Öğrenme Yönteminin Uygulandığı Tezlerin İçerik Analizi." "Content Analyzing of the Thesis Implemented on Cooperative Learning in Turkey", VII. International Congress of Educational Research: 28-30 Mayıs 2015 - Muğla: Abstract (p. 175). Ankara, Pegem.

[24] Kocabaş, A. (2001). 2000'li Yılların Eğitim Felsefesi: Aktif Eğitim. Öğretmen Dünyası Dergisi, Say1: 262, Ankara.

[25] MEB. (2008). Sınıf Öğretmeni Alan Yeterlikleri, Milli Eğitim Bakanlığı Öğretmen Yetiştirme ve Eğitimi Genel Müdürlüğü

[26] MEB.(2006). İlköğretim Müzik Dersi Programı. Milli Eğitim Bakanlığı, Talim Terbiye Kurulu Başkanlığı, Ankara

[27] Panitz, T. (1999). The Case for Student Centered Instruction via Collaborative Learning Paradigms.

[28] Roger T. and David W. Johnson .(1994). An Overview of Cooperative Learning, Originally published in: J. Thousand, A. Villa and A. Nevin (Eds), Creativity and Collaborative Learning; Brookes Press, Baltimore, 1994.

[29] Roseth, C. J., Johnson, D. W., \& Johnson, R. T. (2008). Promoting early adolescents' achievement and peer relationships: the effects of cooperative, competitive, and 
individualistic goal structures. Psychological bulletin, 134(2), 223.

[30] Sümer, N. (2000). Yapısal Eşitlik Modelleri. Türk Psikoloji Yazilar1, 3 (6), 49-74.

[31] Tabachnick, B. G. ve Fidel, L. S. (2001). Using multivariate statistics. Needham Heights, MA: Allyn \& Bacon.

[32] Tarım, K. (2003). Kubaşık öğrenme yönteminin matematik öğretimindeki etkinliği ve kubaşı öğrenme yöntemine ilişkin bir meta analiz çalışması. Doktora tezi, Çukurova Üniversitesi, Fen Bilimleri Enstitüsü, Adana.
[33] Tavşancıl, E. (2010). Tutumların ölçülmesi ve SPSS ile veri analizi. Nobel Yayın Dağıtım: Ankara.

[34] YÖK. (1998). Eğitim Fakültesi Öğretmen Yetiştirme Lisans Programlar1, Ankara, p.3.

[35] YÖK. (1998). Türk Yüksek Öğretiminin Bugünkü Durumu.

[36] YÖK-DÜNYA BANKASI. (1998). Fakülte-Okul İşbirliği Kitabı. Milli Eğitimi Geliştirme Projesi Hizmet Öncesi Öğretmen Eğitimi, Ankara 